\title{
Pemberian Tepung Daun Pepaya (Carica Papaya) Dalam Ransum Terhadap Organoleptik (Danging) Burung Puyuh (Coturnix-coturnik Javonica)
}

\author{
Qomraini Simamora $^{1}$, Aisyah Nurmi ${ }^{2}$, Muharram Fajrin Harahap ${ }^{3}$ \\ ${ }^{1}$ Alumni Fakultas Peternakan Program Studi Peternakan Universitas Muhammadiyah \\ Tapanuli Selatan, e-mail : qomrainisimamora565@gmail.com \\ ${ }^{2}$ Dosen Program Studi Peternakan Fakultas Peternakan Universitas Muhammadiyah \\ Tapanuli Selatan,e-mail : aisyah.nurmi@um-tapsel.ac.id \\ ${ }^{3}$ Dosen Program Studi Agroteknologi Fakultas Pertanian Universitas Muhammadiyah \\ Tapanuli Selatan,e-mail : muharram.fajrin@um-tapsel.ac.id
}

\begin{abstract}
ABSTRAK
Burung puyuh merupakan salah satu ternak yang mudah dibudidayakan dan memiliki peran penting dalam upaya meningkatkan pendapatan masyarakat melalui usaha burung puyuh. Tanaman Pepaya termasuk dalam famili Caricaceae. Daun pepaya mengandung manfaat vitamin C, vitamin A, vitamin E, dan Folat. Penelitian ini bertujuan untuk mengetahui manfaat pemberian tepung daun pepaya (Carica papaya) dalam ransum terhadap organoleptik (Daging) burung puyuh (Coturnix coturnix javonica). Metode penelitian yang digunakan dalam penelitian ini adalah rancangan acak lengkap (RAL) yang terdiri dari 6 perlakuan dan 4 ulangan. Perlakuan R0 (Ransum dengan penambahan tepung daun pepaya 0\%), R1 (Ransum dengan penambahan tepung daun pepaya $5 \%$ ), R2 (Ransum penambahan tepung daun pepaya 10\%), R3 (Ransum penambahan tepung daun pepaya 15\%). Hasil penelitian dapat disimpulkan bahwa untuk uji organoleptik secara uji hedonik dan mutu hedonik terhadap daging dada burung puyuh yang diberi perlakuan ransum dengan penambahan tepung daun pepaya memberikan pengaruh yang nyata terhadap uji hedonik warna dan untuk mutu hedonik rasa (coturnix coturnix javonica).
\end{abstract}

Kata kunci : Tepung daun pepaya, burung puyuh, organoleptik.

\section{PENDAHULUAN}

Masyarakat Indonesia sudah tidak asing lagi dengan burung puyuh kendati hewan ini merupakan binatang liar yang hidup digunung-gunung. Namun beberapa puluh tahun terakhir, ternyata burung liar ini sudah bisa dijinakkan dan dibudidayakan,sertadikembangkan secara komersial. Indonesia dalam pengembangan puyuh memang agak ketinggalan dibandingkan dengan Negara-negara lain seperti Thailand, Malaysia, Jepang dan termasuk amerika serikat. Namun saat ini pengembangan ternak puyuh berkembang pesat, terutama sebelum harga pakan unggas ini naik. 
Pakan adalah campuran berbagai macam bahan organik dan anorganik yang diberikan kepada ternak burung puyuh untuk memenuhi kebutuhan zat-zat makanan yang diperlukan bagi pertumbuhan, perkembangan dan reproduksi. Pakan dengan mutu baik adalah pakan yang mengandung zat-zat makanan seperti karbohidrat, lemak, protein, vitamin, mineral dan air sesuai kebutuhan ternak umur tertentu, sehingga dapat dikonsumsi dan dicerna dalam saluran pencernaan. Pakan dengan mutu baik tentunya dapat menghasilkan produksi ternak dengan baik.

Sayuran yang telah lama dikenal dan di budidayakan secara luas oleh petani diseluruh wilayah Indonesia, bahkan dinegara lain. Tanaman atau sayuran bukan hanya untuk manusia, tetapi juga untuk hewan. Penggunaan sayuran untuk hewan juga telah lama digunakan oleh para petani dan peternak ternyata penggunaannya semakin meningkat.Konsumsi ransum yang sangat tinggi berpotensi dalam meningkatkan kualitas daging. Salah satu cara yang dapat di lakukan untuk meningkatkan kualitas daging adalah pemberian tanaman dari daun pepaya.

Tanaman pepaya (Carica papaya L.)merupakan tanaman yang tumbuh di dataran rendah maupun daratan tinggi, banyak dijumpai di Indonesia sebagai tanaman yang kaya manfaat. Menurut Suryawiria (2002),tanaman pepaya memiliki banyak manfaat mulai dari bagian akar, batang, daun, bunga dan buahnya, yaitu sebagai sumber vitamin, mineral dan senyawa lainnya untuk kebugaran tubuh dan berhasiat dalam bidang kesehatan, memperbaikipencernaan serta menambah nafsu makan. Muhidin (1999)mengatakan bahwa selain sebagai bahanpengempuk daging, yang diproleh dari tanaman pepaya dapat di manfaatkan sebagai bahan obat-obatan.

Sifat fisik daging biasanya berkaitan erat dengan kualitas daging. Sebab kualitas daging dapat diartikan sebagai ukuran sifat-sifat daging yang dikehendak dan dinilai oleh konsumen. Selain dipengaruhi tujuan penggunaan kualitas daging juga dipengaruhi oleh faktor antemortem dan postmortem. Faktor antermortem antara lain lokasi anatomis dan fungsi, kedewasaan fisiologis, tekstur dan ukuran serabut, kebasahan, warna, marbling dan stress. Sedangkan faktor postmortem meliputi laju pendinginan, suspensi karkas, stimulan elektris, pelayuan, pembekuan, dan perlakuan fisik dan kimiawi. Adapun sifat daging yang berpengaruh terhadap kualitas diatas yaitu Water Holding Capacity (WHC), warna (Color). Kesan (Juiceness), keempukan (Cooking Loss), cita rasa (Flavour), struktur dan tekstur, (Nurwantoro dan Mulyani, 2003).

Pengolahan daging lebih sulit dilakukan karena daging merupakan bahan pangan yang mudah rusak. Banyak cara yang dilakukan untuk membuat hasil Pengujian secara organoleptik suatu produk makanan merupakan kegiatan penilaian dengan alat pengindra 
yaitu indera penglihatan, pencicipan, pembau dan pendegar. Melalui hasil pengujianoranoleptik akan diketahuai daya penerimaan panelis (konsumen) terhadap produk.

\section{MATERI DAN METODE PENELITIAN}

\section{Materi Penelitian}

Ternak yang digunakan adalah burung puyuh yang telah dipelihara selama 6 minggu sebanyak 120 ekor yang diperoleh dari Poultry Shop Padangsidimpuan. Daging dada yang berasal dari puyuh jantan sampel yang digunakan sebanyak 24 ekor yang dipelihara sesuai perlakuan. Panelis sebanyak 15 orang yang berasal dari kalangan mahasiswa Fakultas Peternakan Universitas Muhammadiyah Tapanuli Selatan. Bahan yang di gunakan dalam penelitian tusuk sate, arang, pisau, aquades, roti, tissue, piring, lembar kuisioner.

\section{Metode Peneitian}

Rancangan yang digunakan adalah Rancangan Acak Lengkap (RAL) dengan jumlah perlakuan $(\mathrm{t})=4$, ulangan $(\mathrm{n})=6$, Adapun susunan perlakuan ransum adalah sebagai berikut : $\mathrm{R} 0$ = Ransum dengan penambahan tepung daun pepaya $(0 \%), \mathrm{R} 1=$ Ransum dengan penambahan tepung daun pepaya5\%, $\mathrm{R} 2=$ Ransum dengan penambahan tepung daun pepaya10\%, R3 = Ransum dengan penambahan tepung daun pepaya15\%.

Penelitian ini dilakukan dengan menggunakan metode Rancangan Acak Lengkap (RAL) yang terdiri dari 4 perlakuan (R0, R1, R2, R3) dengan ulangan. Model matematika rancangan yang digunakan menurut Steel dan Torrie (1991) adalah:

$$
\mathbf{Y i j}=\boldsymbol{\mu}+\mathbf{T i}+\sum \mathbf{i j}
$$

Keterangan :

Yij = Data pengamatan dari perlakuan pada taraf ke-i dan perlakuan ke-j

$\mu \quad=$ Nilai tengah pengamatan

$\mathrm{Ti}=$ Pengaruh perlakuan ke-i

$\sum \mathrm{ij} \quad=$ Pengaruh galat percobaan dari perlakuan ke-i dan perlakuan k-j

Analisis data dilakukan berdasarkan analisis keragaman. Bila hasilnya berbeda nyata antar perlakuan, maka akan dilakukan uji beda nyata terkecil atau beda nyata jujur atau uji Duncan's (Mattjik dan Sumerta Jaya, 2002),

Apabila $\mathrm{KK}<5 \%$ : Uji lanjut Beda Nyata Jujur (BNJ)

$5<\mathrm{KK}<10 \% \quad$ : Uji Lanjut Beda Nyata Terkecil (BNT)

KK $>10 \% \quad$ : Uji Lanjut Duncan Test

\section{Hasil dan Pembahasan}


Uji Organoleptik merupakan pengujian terhadap bahan makanan berdasarkan kesukaan dan kemauan untuk mempergunakan suatu produk. Uji organoleptik dilakukan dengan menggunakan penilaian skala hedonik terhadap parameter warna, aroma, tekstur dan rasa dari produk tersebut.

\section{Uji hedonik}

Rataan nilai hasil penilaian panelis terhadap uji organoleptik warna, rasa, aroma dan tekstur daging burung puyuh (coturnix-coturnix javonica) dilihat pada Tabel dibawah ini.

Tabel 1 Hasil Penelitian Pengaruh Pemberian Tepung Daun pepaya (Carica papaya) Dalam Ransum Terhadap Warna, Rasa, Aroma, Dan Tekstur Daging Burung Puyuh.

\begin{tabular}{ccccc}
\hline \multirow{2}{*}{ Perlakuan } & \multicolumn{4}{c}{ Parameter } \\
\cline { 2 - 5 } & Warna & Aroma & Tekstur & Rasa \\
\hline R0 & $3.06^{\mathrm{a}}$ & $3.09^{\text {tn }}$ & $3.46^{\text {tn }}$ & $3.36^{\text {tn }}$ \\
R1 & $3.24^{\mathrm{a}}$ & $4.01^{\text {tn }}$ & $3.74^{\text {tn }}$ & $3.69^{\text {tn }}$ \\
R2 & $3.72^{\mathrm{ab}}$ & $3.62^{\text {tn }}$ & $3.51^{\text {tn }}$ & $3.51^{\text {tn }}$ \\
R3 & $4.21^{\mathrm{b}}$ & $3.08^{\text {tn }}$ & $3.72^{\text {tn }}$ & $3.70^{\text {tn }}$ \\
\hline
\end{tabular}

\section{Warna}

Tingkat rataan warna daging burung puyuh pada pemberian tepung daun pepaya (Carica papaya) yang tertinggi dalam perlakuan R3,(Dengan penambahan tepung daun pepaya sebanyak 15\%) dengan skor rata-rata 4.21 suka, dan yang terendah untuk warna daging burung puyuh pada pemberian tepung daun pepaya (Carica papaya) R0,(Dengan penambahan tepung daun pepaya sebanyak $0 \%$ ) memperoleh penilaian dengan skor rata-rata 3.06 (netral). Dari hasil analisis sidik ragam pada Tabel $4.9 \mathrm{~F}$ hitung lebih besar dari $\mathrm{F}$ tabel menunjukkan bahwa warna pada daging burung puyuh memberikan pengaruh yang nyata $(\mathrm{P}<0,05)$.

Untuk mengetahui diantara perlakuan yang memberikan pengaruh nyata terhadap warna daging burung puyuh dilakukan Uji Lanjut Duncan Test dengan KK 16,5968\% seperti yang tertera pada tabel ini.

Tabel 2 Uji Lanjut Duncan Test pemberian tepung daun papaya terhadap warna daging burung puyuh

\begin{tabular}{ccc}
\hline Perlakuan & Rataan & Notasi \\
\hline R0 & 3.06 & $\mathrm{a}$ \\
R1 & 3.25 & $\mathrm{~A}$ \\
R2 & 3.72 & $\mathrm{Ab}$ \\
R3 & 4.21 & $\mathrm{~B}$ \\
\hline
\end{tabular}

Keterangan :Notasi huruf (a,ab,b) yang berbeda menunjukkan berbeda nyata.

Dengan menggunakan Uji Lanjut Duncan Test yang dilakukan dapat dilihat bahwa perlakuan R0, (Dengan penambahan tepung daun pepaya 0\%) dengan rataan 3.06 netral, R1, 
(Dengan penambahan tepung daun pepaya 5\%) dengan rataan 3.25 netral, R2, (Dengan penambahan tepung daun pepaya 10\%) 3.72 suka, kemudian R3, (Dengan penambahan tepung daun pepaya $15 \%$ ) dengan ratan 4.21 suka, berbeda nyata pada pemberian tepung daun pepaya terhadap warna daging burung puyuh, karena panelis lebih menyukai warna daging suka.

Hal ini di sebabkan karena pemberian tepung daun pepaya (Carica papaya) pada daging burung puyuh mempengaruhi mioglobin, hemoglobin, dan pigmen heme yang menentukan warna daging. Menurut Soeparno (2005), faktor-faktor yang mempengaruhi warna daging adalah pakan, spesies, bangsa, umur, jenis kelamin, stres (tingkat aktifitas dan tipe otot), ph dan oksigen.

\section{Aroma}

Aroma merupakan salah satu faktor yang penting dalam menentukan mutu suatu bahan pakan, aroma harum makanan yang dapat ditangkap oleh indra penciuman dan pengecap. Nilai tertinggi tingkat kesukaan panelis terhadap aroma daging burung puyuh ini diperoleh pada aroma daging burung puyuh pada pemberian tepung daun pepaya (Carica papaya) $\mathrm{R} 1$,(Dengan penambahan tepung daun pepya 5\%) dengan skor rata-rata 4.01 suka dan yang terendah untuk aroma daging burung puyuh pada pemberian tepung daun pepaya (Carica papaya) R3,(Dengan penambahan tepung daun pepaya 15\%) memperoleh penilaian dengan skor rata-rata 3.08 netral.

Untuk mengetahui pengaruh perlakuan terhadap tepung daun pepaya (Carica papaya) lebih lanjut, maka dilakukan analisa sidik ragam, Hasil analisis sidik ragam pengaruh perlakuan memberikan hasil tidak nyata terhadap aroma daging burung puyuh diperoleh $\mathrm{F}_{\text {hitung }} 2.81$ dan $\mathrm{F}_{\text {tabel }} 3.10(1 \%)$ dan $4.94(5 \%) . \mathrm{F}_{\text {hitung }}>\mathrm{F}_{\text {tabel }}(1 \%)$ dan $(5 \%)$ hal ini berarti bahwa memberi aroma yang tidak berbau (netral).

\section{Tekstur}

Tekstur merupakan salah satu faktor yang menentukan penerimaan suatu produk. Nilai tertinggi tingkat kesukaan panelis terhadap tekstur daging burung puyuh ini diperoleh pada tekstur daging burung puyuh pada pemberian tepung daun pepaya (Carica papaya) R1, (Dengan penambahn tepung daun pepaya 5\%) dengan skor rata-rata 3.74 suka. Untuk mengetahui pengaruh perlakuan terhadap tepung daun pepaya (Carica papaya) lebih lanjut, maka dilakukan analisa sidik ragam, Hasil analisis sidik ragam pengaruh perlakuan memberikan hasil tidak nyata terhadap tekstur daging burung puyuh diperoleh $\mathrm{F}_{\text {hitung }} 0.36$ dan $\mathrm{F}_{\text {tabel }} 3.10(1 \%)$ dan $4.94(5 \%) . \mathrm{F}_{\text {hitung }}>\mathrm{F}_{\text {tabel }}(1 \%)$ dan $(5 \%)$ hal ini berarti bahwa memberi tekstur yang tidak elastis (netral). 


\section{Rasa}

Rasa merupakan parameter penting untuk menentukan diterima atau tidaknya suatu produk. (Maharani 2009). Nilai tertinggi tingkat kesukaan panelis terhadap rasa daging burung puyuh ini diperoleh pada aroma daging burung puyuh pada pemberian tepung daun pepaya (Carica papaya) (R3) dengan skor rata-rata 3.70 (suka), dan yang terendah untuk rasa daging burung puyuh pada pemberian tepung daun pepaya (Carica papaya) (R0) memperoleh penilaian dengan skor rata-rata 3.36 (netral). Hasil analisis sidik ragam pengaruh perlakuan memberikan hasil tidak nyata terhadap rasa daging burung puyuh diperoleh $\mathrm{F}_{\text {hitung }} 0.49$ dan $\mathrm{F}_{\text {tabel }} 3.10(1 \%)$ dan $4.94(5 \%) . \mathrm{F}_{\text {hitung }}>\mathrm{F}_{\text {tabel }}(1 \%)$ dan $(5 \%)$ hal ini berarti rasa merupakan tanggapan atas adanya rangsangan kimiawi yang sampai diindera pengecap lidah, khususnya jenis rasa dasar yaitu manis, asin, asam, dan pahit.

\section{Uji mutu hedonik}

Rataan nilai hasil penilaian panelis terhadap uji organoleptik warna, rasa, aroma dan tekstur daging burung puyuh (coturnix-coturnix javonica) dilihat pada Tabel dibawah ini.

Tabel 3 Hasil Penelitian Pengaruh Pemberian Tepung Daun Pepaya (carica papaya) Dalam Ransum Terhadap Warna, Rasa, Aroma, Dan Tekstur Daging Burung Puyuh.

\begin{tabular}{ccccc}
\hline \multirow{2}{*}{ Perlakuan } & \multicolumn{4}{c}{ Parameter } \\
\cline { 2 - 5 } & Warna & Aroma & Tekstur & Rasa \\
\hline R1 & $3.22^{\text {tn }}$ & $3.14^{\text {tn }}$ & $3.47^{\text {tn }}$ & $4.02^{\mathrm{b}}$ \\
R0 & $2.63^{\text {tn }}$ & $2.94^{\text {tn }}$ & $3.09^{\text {tn }}$ & $3.80^{\mathrm{a}}$ \\
R2 & $2.70^{\text {tn }}$ & $2.82^{\text {tn }}$ & $3.57^{\text {tn }}$ & $2.93^{\mathrm{b}}$ \\
R3 & $2.68^{\text {tn }}$ & $2.88^{\text {tn }}$ & $3.08^{\text {tn }}$ & $2.87^{\text {ab }}$ \\
\hline
\end{tabular}

\section{Warna}

Tingkat rataan warna daging burung puyuh pada pemberian tepung daun pepaya (Carica papaya) yang tertinggi dalam perlakuan R1, (Dengan penambahan tepung daun pepaya sebanyak 5\% dengan rataan 3.22. (sedang), dan yang terendah dalam perlakuan R0, (Dengan penambahan tepung daun pepaya sebanyak 0\% nilai rataan 2.63 (merah kekuningan). Untuk mengetahui pengaruh perlakuan terhadap tepung daun pepaya (Carica papaya).

Hasil analisis sidik ragam pengaruh perlakuan memberikan hasil tidak nyata terhadap rasa daging burung puyuh diperoleh $\mathrm{F}_{\text {hitung }} 2.12$ dan $\mathrm{F}_{\text {tabel }} 3.10(1 \%)$ dan $4.94(5 \%) . \mathrm{F}_{\text {hitung }}>\mathrm{F}_{\text {tabel }}$ (1\%) dan (5\%). Jika daging segar di potong, warnanya adalah merah kekuningan dari mioglobin. Ketika berada di dalam lingkungan beroksigen, maka permukaan daging segar akan berwarna merah terang karena terjadi oksigenasi mioglobin menjadi oksimioglobin. Oksigen yang masuk ke dalam otot kemudian di pakai untuk reaksi biokimiawi di dalam otot. 
Kondisi ini menghasilkan gradien oksigen dari jenuh di permukaan sampai nol pada beberapa cm di dalam otot (Nugraheni, 2013).

\section{Aroma}

Tingkat rataan aroma daging burung puyuh pada pemberian tepung daun pepaya (Carica papaya) yang tertinggi dalam perlakuan R1 sebesar 3.14 (sedang), dan yang terendah dalam perlakuan R2 sebesar 2.82 (kurang amis). Timbulnya aroma makanan disebabkan oleh terbentuknya senyawa yang mudah menguap agar menghasilkan bau. Zat-zat itu harus dapat menguap sedikit larut dalam air, dan sedikit dapat larut dalam lemak.

Hasil analisis sidik ragam pengaruh perlakuan memberikan hasil tidak nyata terhadap rasa daging burung puyuh diperoleh $\mathrm{F}_{\text {hitung }} 2.22$ dan $\mathrm{F}_{\text {tabel }} 3.10(1 \%)$ dan $4.94(5 \%) . \mathrm{F}_{\text {hitung }}>\mathrm{F}_{\text {tabel }}(1 \%)$ dan $(5 \%)$.Kadar perlemakan dan umur yang tidak berbeda pada daging paha burung puyuh masing-masing perlakuan. Seperti yang dikemukakan Amerineet al. (1965), bahwa kadar lemak dan umur banyak mempengaruhi aroma. Umur ternak yang lebih tua mempunyai aroma yang lebih kuat dari pada daging ternak muda.

\section{Tekstur}

Rataan nilai tekstur daging burung puyuh pada pemberian tepung daun pepaya (Carica papaya) yang tertinggi dalam perlakuan R2 sebesar 3.57 (lunak), dan yang terendah dalam perlakuan R3 sebesar 3.08 (agak lunak). Hasil analisis sidik ragam pengaruh perlakuan memberikan hasil tidak nyata terhadap rasa daging burung puyuh diperoleh $F_{\text {hitung }} 1.72$ dan $\mathrm{F}_{\text {tabel }} 3.10(1 \%)$ dan $4.94(5 \%) . \mathrm{F}_{\text {hitung }}>\mathrm{F}_{\text {tabel }}(1 \%)$ dan (5\%). Hal ini disebabkan karena tidak berbedanya cara pemeliharaan dan umur burung puyuh pedaging yang digunakan pada semua. Perlakuan tingkat kekasaran tekstur meningkat dengan bertambahnya umur.Otot ternak jantan mempunyai tekstur yang lebih besar dari pada otot ternak betina.Bangsa ternak juga mempengaruhi tekstur otot (Bendall, 1973).Tekstur merupakan penentu yang paling penting pada kualitas daging.

\section{Rasa}

Rataan nilai rasa daging burung puyuh pada pemberian tepung daun pepaya (Carica papaya), yang tertinggi dalam perlakuan R1 sebesar 4.02 (gurih), dan yang terendah dalam perlakuan R0 sebesar 2.80 (sedang). Hasil analisis sidik ragam menunjukkan pengaruh perlakuan memberikan hasil nyata terhadap rasa daging burung puyuh.

Hal ini disebabkan karena $F_{\text {hitung }}$ lebih besar dari $F_{\text {tabel. }}$.Rasa merupakan kualitas sensoris daging yang berkaitan dengan indera perasa. Winarno (1997), menyatakan bahwa rasa merupakan faktor penentu daya terima konsumen terhadap produk pangan. Rasa 
dipengaruhi oleh senyawa kimia, suhu, konsentrasi, dan interaksi dengan komponen rasa yang lain.

Untuk mengetahui diantara perlakuan yang memberikan pengaruh nyata terhadap rasa daging burung puyuh dilakukan uji beda nyata terkecil (BNT) dengan KK 9,5656\% seperti tertera pada tabel dibawah ini.

Tabel 4 Uji BNTpemberian perlakuan terhadap rasa daging burung puyuh

\begin{tabular}{ccc}
\hline Perlakuan & Rataan & Notasi \\
\hline R1 & 4.021 & $\mathrm{~b}$ \\
R0 & 3.808 & $\mathrm{a}$ \\
R2 & 2.938 & $\mathrm{~b}$ \\
R3 & 2.876 & $\mathrm{ab}$ \\
\hline
\end{tabular}

Keterangan : Notasi huruf (a,b,ab)yang berbeda menunjukkan berbeda nyata.

Tabel uji BNT yang dilakukan data dilihat bahwa perlakuan R1, R2, R3 memberikan pengaruh nyata pada pertambahan daging burung puyuh pada pemberian daun pepaya, sedangkan pada perlakuan R0 tidak memberikan pengaruh yang nyata pada daging burung puyuh

\section{KESIMPULAN}

Berdasarkan uji organoleptik melalui uji hedonik pemberian tepung daun pepaya (Carica Papaya)dalam ransumterhadap organoleptik (Daging)burung puyuh (Coturnix coturnix javonica), menunjukan rasa (suka) terhadap warna, aroma, tekstur dan rasa, sedangkan melalui uji mutu hedonik dihasilkan warna (sangat merah), aroma (sedang), tekstur (lunak) dan rasa (sangat gurih).

\section{DAFTAR PUSTAKA}

Amerine, M.A, R.M. Pangborn, E.B. Rockssler. (1965). Princi ples of Sensory Evaluation of Food, Acad emic Press, New York and London.

Bendall, J.R. 1973. The Structure and Function of muscle. Vol 2 Ed. G.H.Borne, Academic.

Muhidin. 1991.Agroindustri Papain dan Pektin. Pt. Penebar Swadaya.Jakarta.

Nugroho dan Mayun I.G.T, 1986. Berternak burung puyuh. Eka offset, Semarang. 
Soeparno. 2005. Ilmu dan Teknologi Daging, Cetakan III. Gadjah Mada University Press. Yogyakarta.

Stell.R.G.D. And Torri.J.H. Priciples And Procedures of Statisties. Mc. Grow. Hill Bokk Co. Inc. Newyork.

Suryawiria. 2002. Tanaman Berhasiat Sebagai Obat. Papas Sinar Sinanti. Jakarta.

Winarno,SF. G. 1997. Kimia pangan dan Gizi. Gramedia: Jakarta.

Stell.R.G.D. And Torri.J.H. Priciples And Procedures of Statisties. Mc. Grow. Hill Bokk Co. Inc. Newyork. 